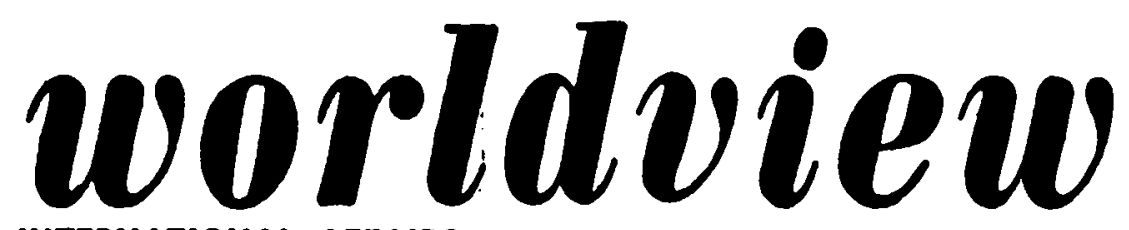

a JOURNAL OF RELIGION AND INTERNATIONAL AFFAIRS

\title{
AFTER THE VISIT
}

We now know that Nikita Khrushchev hates the can-can-and this is about the only new thing be told us during his bizarre sojourn in our country. If the Russian Premier was "educated" by his tour of America, he managed to conceal it. As for any concrete agreements that may have been achieved at Camp David, they are effectively obscured in official pronouncements.

Despite the lack of immediately tangible results, however, a man would have to be literalminded indeed to say at this point that the Khrushchev visit was a failure-or, worse, a disaster. The Spirit of Camp David may indeed prove as insubstantial a thing as its fragile ancestor, the Spirit of Geneva. But history is not determined, and "education" is a subtle thing. It would be impossible for a mind as inquisitive, as pragmatic, as Mr. Khrushchev's to close itself entirely to all new impressions, just as it is impossible that the American people, after seeing the Premier in action on their own soil, should not better understand both the strength and the weakness of the challenge they face.

The visit of the Soviet chief was also a test of the maturity of the American people in their new role as leaders of the democratic world. As William Miller observes elsewhere in this issue, this is a role for which neither our history nor our national psychology has prepared us. We are used to having things our own way and we are not much given to the making of nice distinctions between moral approval and diplomatic necessity. It is only a few years ago that, as the representative of the new Eisenhower administration, Mr. Henry Cabot Lodge went to the United Nations and announced that he would not shake hands with the Soviet delegates. But last month $\mathrm{Mr}$. Lodge accompanied Premier Thrushchev on his tour and the administration be represents requested the American people to receive the Russian leader "courteously."

Since the Khrushchev visit was one of the most important occasions the American people have ever had to demonstrate their responsibility, it would be encouraging to observe that the nation's religious spokesmen supplied them strong leadership. Unfortunately the voices of official religion were curiously divided. There were requests for prayers for the success of this venture, but there were also lamentations to suggest that the very act of negotiation was a moral betrayal. There were pleas for courtesy but there were also near incitements to riot.

A delegation from the National Council of Churches, for example, assured the President of their support and asked for prayers that his talks with Mr. Khrushchev might promote peace; Archbishop Karl Alter of Cincinnati, Ohio reminded his people that though negotiating with Communist leaders "may be distasteful and at times humiliating," such negotiation "is a lesser evil than war itself'; and the Catholic Bishop of Pittsburgh, John J. Wright, publicly urged all the people of that city to receive the Premier courteously.

But other prominent-and in some cases eminent-clerics, both Protestant and Catholic, called for demonstrations and mourning. One distinguished churchman expressed his hope that "a wave of honest indignation" should roll across the United States "to cleanse the air from the contamination" of the Khrushchev visit. "If we were silent while this personified obscenity stalks our land," the prelate declared, "we would be craven cowards."

Apart from any questions about the seemliness of this language in the pronouncements of a Christian, we would suggest that such emoting was surely not helpful to the Republic at a time when great discretion and balance were needed.

But the world leader of one of the great Christian Churches, Pope John XXIII, surely spoke the authentic religious word when, during the Khrushchev visit, he said that "all religious men" had "an obligation" to follow these exchanges "with prayers" that peace with justice might be their fruit. As negotiations go forward, this will continue to be religion's hope. 